\title{
Heavy metal remediation in soil with chemical amendments and its impact on activity of antioxidant enzymes in Lettuce (Lactuca sativa) and soil enzymes
}

\author{
Young Kyu Hong ${ }^{1}$, Jin Wook Kim ${ }^{1}$, Sang Phil Lee ${ }^{2}$, Jae E. Yang ${ }^{2}$ and Sung Chul Kim ${ }^{*}$ (1)
}

\begin{abstract}
Chemical amendments have been used to remediate soils contaminated with heavy metals. However, there is little understanding on the impacts of these amendments on the physiological and biochemical functions of plants and soil. This study used in situ microcosm experiment to understand the effect of chemical amendments on antioxidant and soil enzyme activity in plant and soil with respect to heavy metal reduction. Three chemical amendments-acid mine drainage sludge (AMDS), limestone (LS), and steel slag (SS) —were applied to soil at 3, 5, and 10\% mixing ratios, and lettuce (Lactuca sativa) was cultivated in that soil for 30 days. The results showed that bioavailable $\mathrm{Cd}$ and $\mathrm{Pb}$ in soil was reduced by $9.8-40.5 \%$ and $4.2-92.5 \%$, respectively. The most efficient amendment for heavy metal reduction was AMDS. The uptake of $\mathrm{Cd}$ and $\mathrm{Pb}$ also decreased by $0.5-66.1$ and $21.6-79.5 \%$, respectively, depending on the amendment type and application ratio. The activity of three antioxidants - catalase (CAT), ascorbate peroxidase $(\mathrm{APX})$, and glutathione reductase (GR) - was generally higher than the control with no amendments. This result indicated that there was minimal inhibition of antioxidant activity due to the reduction of heavy metal uptake. Also, no significant difference was observed in chemical amendments applied soil compared to control in terms of soil enzyme activity. However, correlation analysis between heavy metal concentration in soil and two soil enzyme activities showed that significantly negative correlation $(p<0.01)$ was observed between bioavailable Pb in soil and acid-phosphatase activity. This result might indicate that impact of bioavailable $\mathrm{Pb}$ was much higher than $\mathrm{Cd}$ in terms of inhibition of soil enzyme activity. Overall, the application of chemical amendments to heavy metal polluted had a positive effect on plant physiological function and soil enzyme activity with a reduction in bioavailable heavy metals in soil and plants.
\end{abstract}

Keywords: Heavy metals, Amendments, Bioaccumulation, Antioxidant, Soil enzymes

\section{Introduction}

Heavy metal pollution in the arable land has been a concern because of the potential for bioaccumulation of hazard heavy metals in crops [1-3], and ultimately pose a

\footnotetext{
*Correspondence: sckim@cnu.ac.kr

${ }^{1}$ Department of Bio Environmental Chemistry, Chungnam National

University, Daejeon 34134, Korea

Full list of author information is available at the end of the article
}

risk to human health [4-6]. Thus, numerous studies have focused on the remediation of heavy metals in soil $[7,8]$.

Heavy metal remediation in soil can apply physical, chemical, and biological techniques depending on land use, pollution level, and time/labor availability [9, 10]. Physical techniques include soil washing [11] and replacement [12] as well as thermal treatment [13]. The main advantage of physical treatment is the high efficiency of the heavy metal removal. However, the management of secondary pollutants, such as acid/alkaline 
chemicals and leachates containing high concentrations of heavy metals, presents another challenge.

Chemical stabilization technique is one of the representative in situ method using different soil amendments including liming materials, organics, clay materials, and metal oxides to immobilize bioavailable fractions of heavy metals in soil [10]. Liming materials such as limestone, oyster/egg shell, and calcium hydroxide $\mathrm{Ca}(\mathrm{OH})_{2}$ generally increase soil $\mathrm{pH}$ and make complexation between hydroxide ions $\left(\mathrm{OH}^{-}\right)$and soluble heavy metals resulting enhancement of the immobilization of heavy metals in soil [14]. Organic compost and biochar are the most common carbon rich materials used as amendments for heavy metal remediation because of their sorption capacity and ionic bonding with functional organics groups $[15,16]$. Clay materials, including sepiolite and zeolite, can increase the partition of soluble heavy metals into carbonate or Fe/Mn oxide [17]. They also increase soil $\mathrm{pH}$ and enhance the precipitation of bioavailable heavy metals in soil [18]. As chemical stabilization techniques are cheap, safe, and eco-friendly, this in situ method has been widely used in Korea [19, 20].

Heavy metal pollution in soil have a great possibility to impact plant growth by altering physiological functions. The formation of reactive oxygen species (ROS) is representative of the damage to plants as ROS adversely impacts on cell membranes, nucleic acids, and chloroplast pigments [21]. When ROS are generated by induced heavy metals, plants activate cellular antioxidative metabolism by producing antioxidant enzymes such as superoxide dismutase (SOD), catalase (CAT), ascorbate peroxidase (APX), glutathione reductase (GR), and peroxidase (POD) as well as non-enzymatic compounds such as cysteine (Cys), carotenoids and ascorbate [22, 23]. The relationship between the bioaccumulation of heavy metals and activation of antioxidant enzymes has been examined in varied plant species $[21,24,25]$. Previous study showed that antioxidant enzymes, CAT, APX, and GR, was found to increase by $2.3-5.3$ times in plants grown in highly polluted soil with heavy metals [21, 26]. Higher concentrations of hazardous heavy metals elevate the stress in plants, thereby increasing the formation of ROS. In order to scavenge ROS, there is an increased production of antioxidant enzymes. In contrast, production of antioxidant enzymes decreases when plants were exposed to heavy metals over a long period of time [25, 26]. This decline of antioxidant enzymes may be attributed to the impairment of the scavenging function of antioxidant enzymes with prolonged metal stress [25]. Thus, monitoring of antioxidant production in plants may provide useful insights to understanding heavy metal toxicity on plant physiological function and growth $[27,28]$.
Soil enzyme activity is also a good indicator of heavy metal toxicity in soil [29]. Common soil enzymes may be categorized into oxidoreductases (polyphenoloxidase (PPO) and catalase for redox control) and hydrolases (amylase, acetylglucosaminidase (NAG), $\beta$-glucosidase (BG), cellulose, invertase, protease, urease, and acid phosphatase for soil nutrients cycling control) [30]. When soil is exposed to high concentrations of hazardous heavy metals, the microbial activity is inhibited and prompted a general decline in soil enzyme activity. A strong negative correlation was observed in catalase production when high concentrations of $\mathrm{Cd}, \mathrm{Cu}, \mathrm{Pb}, \mathrm{Ni}$, and $\mathrm{Zn}$ were introduced in soil via wastewater irrigation from industrial factories [31,32]. Natural or anthropogenic pollution of heavy metals in soil also altered microbial community structure and had an adverse effect on soil enzyme activity [33].

Numerous studies have reported on the effect of heavy metals on plant physiological function and soil enzyme activity. However, there is little detailed information on the effect of chemical amendments on plant and soil enzyme activity following heavy metal remediation. The main objective of this research was to examine (1) the reduction efficiency of heavy metals in soil with chemical amendments, (2) the response of antioxidant activity in plants, and (3) the effect of chemical stabilization techniques on soil enzyme activity.

\section{Materials and methods}

\section{Soil collection and experimental setup}

Heavy metal polluted soil was collected from an agricultural field located within a $2 \mathrm{~km}$ radius of an abandoned metal mine in Korea. Surface soil samples $(0-30 \mathrm{~cm})$ were collected with shovel at five different locations within a $100 \mathrm{~m}^{2}$ area and composited into one sample bag. After transporting soil samples to the laboratory, stone or debris were removed and mixed with 3,5 , and $10 \%(\mathrm{w} / \mathrm{w})$ of each chemical amendment, lime stone (LS), steel slag (SS), and acid mine drainage sludge (AMDS) based on $3.5 \mathrm{~kg}$ of soil. Selected three chemical amendments have been widely used to immobilize bioavailable heavy metals via ionic complexation or precipitation mechanism in soil $[8,26,34,35]$. Total of 30 mixed soil samples including triplicates of each treatment, application level, and control (without mixing chemical amendments) were placed in each container $(\varnothing 23 \times 18 \mathrm{~cm}$ depth $)$ and all containers were randomly placed in the greenhouse. Three grams of chemical fertilizer (N-P-K, 12-10-9) was applied to each container according to the guidelines of the National Academy of Agricultural Science (NAAS) in Korea. After one week of aging, one piece of pre-grown lettuce ( $L a c$ tuca sativa) in the growing medium was transplanted to the middle of each container and cultivated for 30 days. 


\section{Analysis of soil properties}

Soil samples were collected after the lettuce was harvested (30 days after sowing). Half of the soil sample in each container was air-dried for physicochemical and heavy metal analyses. The other half of the sample was kept in the refrigerator at $4{ }^{\circ} \mathrm{C}$ for soil enzyme analysis. The physicochemical properties of the soil samples were measured based on a previous study [36]. Soil texture was measured using the micropipette method, and soil $\mathrm{pH}$ and electrical conductivity (EC) (1:5) were analyzed with a pH (Mettler Toledo, MP 200, Switzerland) and EC (Mettler Toledo, S230, Switzerland) meter after $5 \mathrm{~g}$ soil and $25 \mathrm{~mL}$ of deionized (DI) water were thoroughly mixed in a $50 \mathrm{~mL}$ flask for $1 \mathrm{~h}$. Soil organic matter (OM) was determined using the Walkley Black method, and cation exchange capacity (CEC) was analyzed using a $1 \mathrm{M} \mathrm{CH}_{3} \mathrm{COOH}$ extraction method.

\section{Analysis of heavy metal concentration in soil and plant}

The air-dried soil sample was passed through a $0.15 \mathrm{~mm}$ sieve for heavy metal analysis, and two different extractants were used to extract heavy metals from the soil. Aqua regia ( $\mathrm{HCl}: \mathrm{HNO}_{3}, 3: 1, \mathrm{v} / \mathrm{v}$ ) was used for total concentration and Mehlich-3 was used to determine the bioavailable fraction of heavy metals in the soil. Briefly, $3 \mathrm{~g}$ of soil and $21 \mathrm{~mL}$ of aqua regia were added in the Teflon tube and digested in a heating block (Block Heating Sample Preparation System, Ctrl-M Science) for total heavy metal extraction. In case of Mehlich-3 extraction, $10 \mathrm{~g}$ of soil and $50 \mathrm{~mL}$ of extractant were placed into a $100 \mathrm{~mL}$ polypropylene centrifuge tube and shaken for $1 \mathrm{~h}$ at $30{ }^{\circ} \mathrm{C}$ in an incubation shaker (JSR, JSOS-500, Korea). After shaking, samples were filtered through a $0.45 \mu \mathrm{m}$ filter and filtrates with metal concentrations were measured using inductively coupled plasma-optical emission spectrometry (ICP-OES) (8300DV, Perkin-Elmer, USA).

Harvested plant samples were oven-dried at $65{ }^{\circ} \mathrm{C}$ for 2 days, ground with a grinder, and digested with $5 \mathrm{~mL}$ concentrated $\mathrm{HNO}_{3}$ using a temperature controlled digestion block (OD-98-001, ODLAB, Korea). The digested suspension was then filtered through a $0.45 \mu \mathrm{m}$ cellulose acetate disposable filter, and the metal concentration in the filtered solution was determined using ICPOES (8300DV, Perkin-Elmer, USA).

For quality assurance/quality control (QA/QC) purposes, certified reference materials (CRM) of soil samples (BAM-U112, Federal Institute for Materials Research and Testing, Berlin, Germany) were measured for every 30 samples and verified that recovery ratio of $\mathrm{Cd}$ and $\mathrm{Pb}$ were at the range of $80-120 \%$. In addition, blank and spiked aqueous samples with known concentrations were measured periodically.

\section{Biomass and antioxidant analysis in plants}

To measure the biomass in each treatment only the edible part of the lettuce was thoroughly washed three times with DI water, dried with a paper towel, and weighed to measure the fresh weight.

Antioxidant activity was measured following the method used in a previous study [21, 37, 38]. Frozen leaf samples $(0.2 \mathrm{~g})$ were ground with a mortar and pestle with liquid nitrogen and homogenized with $2 \mathrm{~mL}$ of $25 \mathrm{mM}$ potassium phosphate buffer solution $(\mathrm{pH} 7.8)$ containing $0.4 \mathrm{mM}$ EDTA- $\mathrm{Na}_{2}$ and $2 \%(\mathrm{w} / \mathrm{v})$ polyvinylpyrrolidine-40. The homogenate was centrifuged at $15,000 \mathrm{~g}$ for $20 \mathrm{~min}$ and the supernatant was stored in a refrigerator $\left(4{ }^{\circ} \mathrm{C}\right)$ for antioxidant analysis. CAT activity was monitored at $240 \mathrm{~nm}$ for $1 \mathrm{~min}$ after $0.1 \mathrm{~mL}$ of extracted co-enzyme was mixed with $1.9 \mathrm{~mL}$ of reaction solution containing $1 \mathrm{M}$ potassium phosphate buffer solution and $30 \% \mathrm{H}_{2} \mathrm{O}_{2}$ solution. The APX activity was monitored at $290 \mathrm{~nm}$ for $1 \mathrm{~min}$ using $0.02 \mathrm{~mL}$ of extracted co-enzyme and $1.98 \mathrm{~mL}$ of reaction solution containing $25 \mathrm{mM}$ potassium phosphate buffer solution, $0.25 \mathrm{mM}$ ascorbic acid, $0.1 \mathrm{mM}$ EDTA- $\mathrm{Na}_{2}$, and $0.1 \mathrm{mM}$ $\mathrm{H}_{2} \mathrm{O}_{2}$. Finally, the activity of GR was monitored at $340 \mathrm{~nm}$ for 1 min using $0.1 \mathrm{~mL}$ extracted co-enzyme and $1.9 \mathrm{~mL}$ reaction solution containing $25 \mathrm{mM}$ potassium phosphate buffer solution, $0.5 \mathrm{mM}$ L-glutathion oxidized (GSSG), and $0.12 \mathrm{mM}$ nicotinamide adenine dinucleotide phosphate (NADPH).

\section{Soil enzyme analysis}

Two different soil enzyme activities, $\beta$-glucosidase and acid phosphatase, were evaluated based on a previous study [39]. To analyze $\beta$-glucosidase, $0.5 \mathrm{~g}$ of fresh soil was incubated at $30^{\circ} \mathrm{C}$ for $1 \mathrm{~h}$ to convert p-nitrophenyl$\beta$-glucoside (PNG) into p-nitrophenol (PNP), and UV/vis spectrometer measurements were conducted at $400 \mathrm{~nm}$. For phosphatase analysis, $1 \mathrm{~g}$ of fresh soil was incubated at $37{ }^{\circ} \mathrm{C}$ for $1 \mathrm{~h}$ after the addition of $0.2 \mathrm{~mL}$ toluene, $0.025 \mathrm{M}$ p-nitrophenyl phosphate (pNPP), and $1 \mathrm{~mL}$ of modified universal buffer (MUB, $\mathrm{pH}$ 6.5) to the test tube. Then, $4.0 \mathrm{~mL}$ of $0.5 \mathrm{M} \mathrm{NaOH}$ and $1 \mathrm{~mL}$ of $0.5 \mathrm{M}$ $\mathrm{CaCl}_{2}$ were added to quench the reaction. The filtrate was measured with a UV/vis spectrometer at $400 \mathrm{~nm}$. A calibration curve for both $\beta$-glucosidase and phosphatase was generated with a $0.1 \mathrm{M}$ Tris buffer solution mixed with p-nitrophenol between 0.4 and $1.7 \mu$ g. Soil enzyme activity was expressed as $\mu \mathrm{g}$ p-nitrolphenol produced by $1 \mathrm{~g}$ dry weight soil/h.

\section{Data analysis}

All measured values were the average of triplicate measurements and statistical analysis, analysis of variance 
(ANOVA), and correlation analysis, were conducted using SPSS (Ver. 22) with a significance of $\mathrm{p}<0.05$ and $\mathrm{p}<0.01$.

\section{Results and discussion}

\section{Changes to soil properties with chemical amendment} application

The soil texture was sandy loam and chemical properties such as soil pH (5.54), EC (0.10 dS m $\left.{ }^{-1}\right)$, SOM (1.50\%), and available $\mathrm{P}_{2} \mathrm{O}_{5}\left(42.4 \mathrm{mg} \mathrm{kg} \mathrm{mg}^{-1}\right)$ were typical of the upland soil in Korea (Table 1). Table 2 summarizes the soil chemical properties following 30 days of lettuce cultivation. Soil $\mathrm{pH}$ increased in all treatments compared to the control. Significantly high soil $\mathrm{pH}(\mathrm{p}<0.05)$ was observed in the LS and SS treatments, while no significant difference was observed in the AMDS treatment. The highest increase in soil pH (7.12) was observed when $10 \%$ SS was applied. LS and SS are widely used chemical amendments to remediate heavy metal polluted soils due to their ability to increase soil $\mathrm{pH}$. As soil $\mathrm{pH}$ is increased, soluble fraction of heavy metals can make a complexation or bonding with ions and enable the immobilization of soluble heavy metals in soil $[8,34,40]$.

\section{Bioavailable heavy metal concentration in soil}

The bioavailable fraction of heavy metals in the soil for each treatment after the lettuce was harvested is shown in Fig. 1. The reduction efficiency of bioavailable $\mathrm{Cd}$ and $\mathrm{Pb}$ in the treatment compared to the control was in the range of $9.8-40.5$ and $4.2-92.5 \%$, respectively. Among
Table 2 Physicochemical properties of soil in each treatment after 30 days of chemical amendment application

\begin{tabular}{llllll}
\hline Treatments & $\mathbf{w} / \mathbf{w}$ & $\mathbf{p H}$ & $\mathbf{E C}^{\mathbf{a}}$ & Organic matter & $\mathbf{A v} \cdot \mathbf{P}_{\mathbf{2}} \mathbf{O}_{\mathbf{5}}^{\mathbf{b}}$ \\
\hline \multirow{3}{*}{ Control } & $\%$ & $(1.5)$ & $\mathrm{dS} \mathrm{m^{-1 }}$ & $\%$ & $\mathrm{mg} \mathrm{kg}^{-1}$ \\
AMDS & & $5.54 \mathrm{a}$ & $0.10 \mathrm{~cd}$ & $1.5 \mathrm{abc}$ & $42.4 \mathrm{~d}$ \\
& 3 & $5.87 \mathrm{a}$ & $0.10 \mathrm{bcd}$ & $1.5 \mathrm{bc}$ & $26.7 \mathrm{bc}$ \\
& 5 & $5.75 \mathrm{a}$ & $0.09 \mathrm{abc}$ & $1.6 \mathrm{bc}$ & $24.9 \mathrm{ab}$ \\
LS & 10 & $5.77 \mathrm{a}$ & $0.16 \mathrm{e}$ & $1.6 \mathrm{bc}$ & $16.2 \mathrm{a}$ \\
& 3 & $6.70 \mathrm{~b}$ & $0.11 \mathrm{~cd}$ & $1.6 \mathrm{bc}$ & $38.9 \mathrm{~d}$ \\
& 5 & $6.92 \mathrm{bc}$ & $0.15 \mathrm{e}$ & $1.8 \mathrm{c}$ & $39.0 \mathrm{~d}$ \\
SS & 10 & $6.85 \mathrm{bc}$ & $0.13 \mathrm{de}$ & $1.6 \mathrm{bc}$ & $39.3 \mathrm{~d}$ \\
& 3 & $6.55 \mathrm{~b}$ & $0.07 \mathrm{ab}$ & $1.5 \mathrm{abc}$ & $42.8 \mathrm{~d}$ \\
& 5 & $6.81 \mathrm{bc}$ & $0.10 \mathrm{bc}$ & $1.5 \mathrm{abc}$ & $44.5 \mathrm{~d}$ \\
& 10 & $7.12 \mathrm{c}$ & $0.10 \mathrm{bc}$ & $1.5 \mathrm{ab}$ & $35.4 \mathrm{~cd}$ \\
\hline
\end{tabular}

All value is an average of triplicated measurement. Different letter indicates measured value is significantly different in different treatment $(p<0.05)$

a EC: Electrical conductivity

b Av. $\mathrm{P}_{2} \mathrm{O}_{5}$ : Available $\mathrm{P}_{2} \mathrm{O}_{5}$

the three amendments, SS and AMDS showed the highest reduction efficiency for $\mathrm{Cd}$ and $\mathrm{Pb}$, respectively while LS showed the least reduction efficiency. In case of varied application ratio, no significant difference was observed in each treatment with the exception of AMDS for $\mathrm{Pb}$.

AMDS generally contains iron oxide or iron sulfate hydroxide, and these two dominant chemical compositions were able to form complexes with the cation forms

Table 1 Physicochemical properties and heavy metal concentration of soil and chemical amendments used in the experiment

\begin{tabular}{|c|c|c|c|c|}
\hline Properties & Soil & AMDS & LS & SS \\
\hline \multicolumn{5}{|l|}{ Soil texture } \\
\hline Sand (\%) & 67.7 & & & \\
\hline Silt (\%) & 15.5 & & & \\
\hline Clay (\%) & 16.8 & & & \\
\hline \multicolumn{5}{|l|}{ Sandy loam } \\
\hline $\mathrm{pH}(1: 5)$ & $5.54 \pm 0.05$ & $7.85 \pm 0.03$ & $10.35 \pm 0.02$ & $12.43 \pm 0.01$ \\
\hline $\mathrm{EC}\left(\mathrm{dS} \mathrm{m}^{-1}\right)$ & $0.10 \pm 0.01$ & $0.59 \pm 0.01$ & $0.35 \pm 0.02$ & $0.76 \pm 0.04$ \\
\hline $\mathrm{OM}(\%)$ & $1.50 \pm 0.08$ & & & \\
\hline Av. $\mathrm{P}_{2} \mathrm{O}_{5}{ }^{\mathrm{a}}\left(\mathrm{mg} \mathrm{kg}^{-1}\right)$ & $42.4 \pm 6.80$ & & & \\
\hline Total-Cd $\left(\mathrm{mg} \mathrm{kg}^{-1}\right)$ & $2.60 \pm 0.02$ & $2.20 \pm 0.32$ & $0.20 \pm 0.01$ & $2.18 \pm 0.03$ \\
\hline Total-Pb (mg kg $\left.{ }^{-1}\right)$ & $1,289 \pm 27.7$ & $15.9 \pm 3.50$ & $8.30 \pm 1.32$ & $9.0 \pm 5.2$ \\
\hline $\mathrm{CaO}^{\mathrm{b}}(\%)$ & & 4.03 & 97.8 & 29.3 \\
\hline $\mathrm{SiO}_{2}(\%)$ & & 6.93 & 0.76 & 12.2 \\
\hline $\mathrm{Al}_{2} \mathrm{O}_{3}(\%)$ & & 5.91 & 0.40 & 6.00 \\
\hline $\mathrm{Fe}_{2} \mathrm{O}_{3}(\%)$ & & 80.3 & 0.33 & 41.6 \\
\hline
\end{tabular}

a Av. $\mathrm{P}_{2} \mathrm{O}_{5}$ : Available $\mathrm{P}_{2} \mathrm{O}_{5}$

b Representative 4 elements of each chemical amendment measured with $\mathrm{X}$-ray fluorescence 


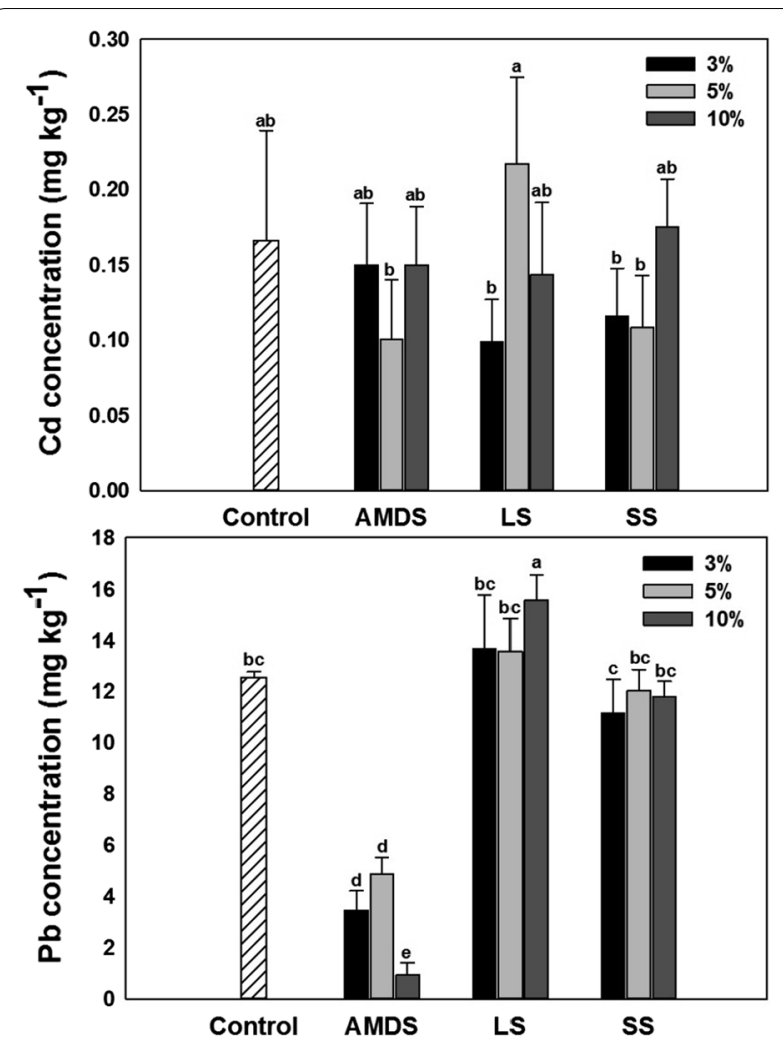

Fig. 1 Bioavailable heavy metal concentration in soil with different amendments after 30 days of lettuce (Lactuca Satva) cultivation. All value was an average of triplicate measurement and error bar represent standard deviation. Different letters represent statistical difference at the significance of $p<0.05$

of $\mathrm{Cd}$ and $\mathrm{Pb}$ in soil $[36,41]$. Although the main reduction mechanism with AMDS application in soil for heavy metal stabilization was not confirmed in this study, result of XRF measurement in our study revealed that much higher content of $\mathrm{Fe}_{2} \mathrm{O}_{3}$ in AMDS (80.3\%) compared to LS (0.33\%) and SS (41.6\%) might contribute complexation of soluble $\mathrm{Cd}$ and $\mathrm{Pb}$ in soil (Table 1). Previous study had also identified that the application of AMDS was effective in reducing the bioavailable fraction of heavy metals in soil due to FeO-related complexation [36, 42].

In the case of SS treatment, reduction rate of 5.2-34.9\% for $\mathrm{Cd}$ and $4.2-11.2 \%$ for $\mathrm{Pb}$ was observed. Previous study reported that the main reduction mechanism for bioavailable heavy metals in soil with SS treatment could be sorption, precipitation, and ion exchange [37]. The SS surface is mainly composed of minerals such as $\mathrm{TiO}_{2}$, $\mathrm{FeO}_{3}, \mathrm{FeO}, \mathrm{Fe}_{3} \mathrm{O}_{4}, \mathrm{BaO}, \mathrm{MgO}, \mathrm{CaO}, \mathrm{MnO}$, and $\mathrm{SiO}_{2}$, and can make a complexation with the cation forms of $\mathrm{Cd}$ and $\mathrm{Pb}$ in soil. Moreover, the addition of SS increase soil $\mathrm{pH}$ and reduce the bioavailable fraction of $\mathrm{Cd}$ and $\mathrm{Pb}$ in soil. Although significantly different reduction efficiency for bioavailable $\mathrm{Cd}$ and $\mathrm{Pb}$ was not observed in $\mathrm{SS}$ treatment, alkaline property ( $\mathrm{pH}: 12.43$ ) and of content of $\mathrm{Fe}_{2} \mathrm{O}_{3}(41.6 \%)$ might contribute reduction of bioavailable $\mathrm{Cd}$ and $\mathrm{Pb}$ in soil (Table 1 ).

Numerous studies have reported that LS is an efficient soil amendment for heavy metal remediation as it increases soil $\mathrm{pH}$, precipitates hydroxyl forms of heavy metals, and subsequently reduces the bioavailable forms of heavy metals in soil [35, 40, 43, 44]. However, no significant reduction efficiency was observed in our study. This may be because $65 \%$ of LS used in our study was distributed at $1 \mathrm{~mm}<\mathrm{GS}<2 \mathrm{~mm}$ of the grain size (data not shown). Bigger grain sizes of LS compared to AMDS and SS $(0.15 \mathrm{~mm}<\mathrm{GS}<1 \mathrm{~mm})$ may decrease the efficiency of heavy metal reduction in soil [45]. In addition, smaller grain size of AMDS showed high efficiency of heavy metal reduction in soil compared to bigger grain size of LS and SS because of sorption capacity [36].

Correlation analysis revealed that soil $\mathrm{pH}$ and available $\mathrm{P}_{2} \mathrm{O}_{5}$ were significantly correlated $(\mathrm{p}<0.01)$ with bioavailable $\mathrm{Pb}$ in the soil (Table 3). A strong positive correlation between bioavailable $\mathrm{Pb}$ concentration and soil $\mathrm{pH}$ or available $\mathrm{P}_{2} \mathrm{O}_{5}$ indicate that increased soil $\mathrm{pH}$ and available $\mathrm{P}_{2} \mathrm{O}_{5}$ concentration enabled an increase in the concentration of bioavailable $\mathrm{Pb}$ in the soil. This result is inconsistent with a previous study showing that increasing soil $\mathrm{pH}$ is the main mechanism reducing bioavailable cation heavy metals, including $\mathrm{Pb}$, in soil $[19,20,46]$. In our study, AMDS had the highest reduction efficiency for bioavailable $\mathrm{Pb}$ in soil, not LS and SS. As the reduction mechanism of AMDS was complexation between heavy metals and iron oxide or iron sulfate hydroxide, we may conclude that soil $\mathrm{pH}$ had a minimal impact on the reduction of bioavailable $\mathrm{Pb}$ while soluble ion complexation between heavy metal and iron had more impact on reducing bioavailable $\mathrm{Pb}$ in soil $[36,41]$.

In case of $\mathrm{Pb}-\mathrm{P}$ correlation, previous study pointed out that addition of $\mathrm{P}$ containing amendment can reduce $\mathrm{Pb}$ concentration in soil by immobilization or precipitation mechanism [47, 48]. However, acidic condition of soil can release soluble $\mathrm{P}$ into soil [48] and positive correlation could be observed between $\mathrm{Pb}$ and $\mathrm{P}$ concentration in soil.

\section{Heavy metal uptake and biomass of lettuce}

Heavy metal concentrations in lettuce is shown in Fig. 2. Compared to the control, the uptake of $\mathrm{Cd}$ and $\mathrm{Pb}$ was reduced by $0.5-66.1$ and $21.6-79.5 \%$, respectively, depending on the amendments and application ratio. The highest reduction of Cd was observed in 5\% LS (66.1\%) and 3\% AMDS for $\mathrm{Pb}$ (79.5\%). Among the three amendments, LS had the highest reduction for Cd and AMDS for $\mathrm{Pb}$ in lettuce. 
Table 3 Correlation analysis between heavy metal concentration and biochemical properties in soil

\begin{tabular}{|c|c|c|c|c|c|c|c|c|c|c|c|c|c|}
\hline & $\mathrm{pH}$ & EC & OM & $\mathrm{P}_{2} \mathrm{O}_{5}$ & Cd_Soil & Pb_Soil & Cd_Plant & Pb_Plant & CAT & GR & APX & GLY & PHOS \\
\hline $\mathrm{pH}$ & 1.000 & & & & & & & & & & & & \\
\hline EC & 0.029 & 1.000 & & & & & & & & & & & \\
\hline $\mathrm{OM}$ & -0.035 & $0.682^{* *}$ & 1.000 & & & & & & & & & & \\
\hline P2O5 & $0.475^{* *}$ & -0.006 & 0.062 & 1.000 & & & & & & & & & \\
\hline Cd_Soil & 0.058 & 0.287 & 0.115 & 0.046 & 1.000 & & & & & & & & \\
\hline Pb_Soil & $0.654^{* *}$ & 0.195 & 0.162 & $0.827^{* *}$ & 0.126 & 1.000 & & & & & & & \\
\hline Cd_Plant & -0.060 & -0.361 & -0.354 & $0.436^{*}$ & -0.308 & 0.184 & 1.000 & & & & & & \\
\hline Pb_Plant & 0.078 & -0.301 & -0.049 & $0.507^{* *}$ & -0.243 & $0.417^{*}$ & $0.586^{* *}$ & 1.000 & & & & & \\
\hline CAT & 0.048 & 0.232 & 0.306 & 0.247 & 0.025 & 0.116 & 0.052 & -0.094 & 1.000 & & & & \\
\hline GR & -0.044 & -0.060 & 0.098 & -0.217 & -0.333 & -0.178 & 0.005 & -0.042 & -0.082 & 1.000 & & & \\
\hline APX & -0.012 & -0.080 & 0.135 & 0.033 & 0.135 & -0.113 & -0.147 & -0.078 & 0.180 & -0.128 & 1.000 & & \\
\hline GLY & $0.366^{*}$ & 0.120 & -0.036 & 0.070 & 0.181 & 0.167 & -0.289 & -0.167 & 0.188 & -0.072 & 0.190 & 1.000 & \\
\hline PHOS & $-0.644^{* *}$ & -0.186 & -0.140 & $-0.559^{* *}$ & -0.234 & $-0.753^{* *}$ & 0.074 & -0.196 & -0.140 & 0.330 & 0.344 & -0.163 & 1.000 \\
\hline
\end{tabular}

All value is an average of triplicated measurement

CAT catalase, APX ascorbate peroxidase, GR glutathione reductase (GR), GLY $\beta$-glucosidase, $P H O S$ phosphatase

$*(p<0.05)$

** $(p<0.01)$ indicates that measured value is significantly different in varied parameters

Uptake of heavy metal is mainly occurred when ionic forms of heavy metals are sorbed in the root and translocated to other compartments such as stems, leaves, or fruits. In this process, sorption of heavy metals in root is highly dependent on soil properties such as soil $\mathrm{pH}$, organic matter contents, and nutrient level in soil $[49,50]$. Higher soil $\mathrm{pH}$ and organic matter content can enhance immobilization of heavy metals in soil due to complexation and ionic bonding mechanism [51]. Correlation analysis in Table 3 showed that $\mathrm{Cd}$ and $\mathrm{Pb}$ concentration in the lettuce is negatively correlated to soil $\mathrm{pH}$ and organic matter content in soil except positive correlation between $\mathrm{Pb}$ in lettuce and soil $\mathrm{pH}$. This result agreed with the previous study that increased soil $\mathrm{pH}$ and organic matter concentration increased immobilization of heavy metals in paddy or upland soil and decreasing uptake to the crops $[2,15,16]$.

In case of soluble phosphorus $\left(\mathrm{P}_{2} \mathrm{O}_{5}\right)$, positive correlation was observed with $\mathrm{Cd}$ and $\mathrm{Pb}$ concentration in soil and plant indicating that higher soluble $\mathrm{P}$ increased uptake of $\mathrm{Cd}$ and $\mathrm{Pb}$ in the lettuce (Table 3). Phosphorus $(\mathrm{P})$ is an essential nutrient for crop growth and phosphorus fertilizer also has been used to remediate heavy metals in soil by making non-soluble phosphate precipitates [3, 52]. However, contrast result was observed in our study and the reason could be assumed that AMDS treated soil showing the most efficient reduction for bioavailable heavy metals in soil contained the lowest soluble P compared to other treatments. Therefore, effect of soluble $\mathrm{P}$ on reducing bioavailable heavy metals in soil was minimal in this study.
Fresh weight of lettuce cultivated after 30 days of each treatment is shown in Fig. 2. Although no significant difference was observed in the treatment compared to the control, the fresh weight was generally in the order SS > LS > AMDS. The highest fresh weight (80.6 g) was observed when $10 \%$ SS was applied followed by $5 \%$ SS (70.8 g).

\section{Antioxidant enzyme activity in the lettuce}

Compared to the control, no significant difference ( $p>0.05$ ) was observed for the activity of three antioxidant enzymes, CAT, APX, and GR, in all three amendments except APX activity in 3\% AMDS application (Fig. 3). Additionally, there were no variables, including soil chemical properties and heavy metal concentrations in the soil and plants, that had a significant correlation with antioxidant enzymes in plants (Table 3 ).

However, generally higher antioxidant enzyme activity was observed when chemical amendments were applied. This result is consistent with a previous study reporting that antioxidant enzyme activity in plant cells was stimulated when amendments (biochar and chitosan) were applied to reduce the uptake of heavy metals in soil [39]. When heavy metal concentrations are high in soil, the activity of antioxidant enzymes such as CAT, APX, and GR as a preventive system is inhibited and the generation of reactive oxygen species (ROS) increases [49]. The application of amendments had an effect on reducing bioavailable heavy metal concentrations in soil and consequently, decreasing the inhibition of antioxidant activity in plants. 

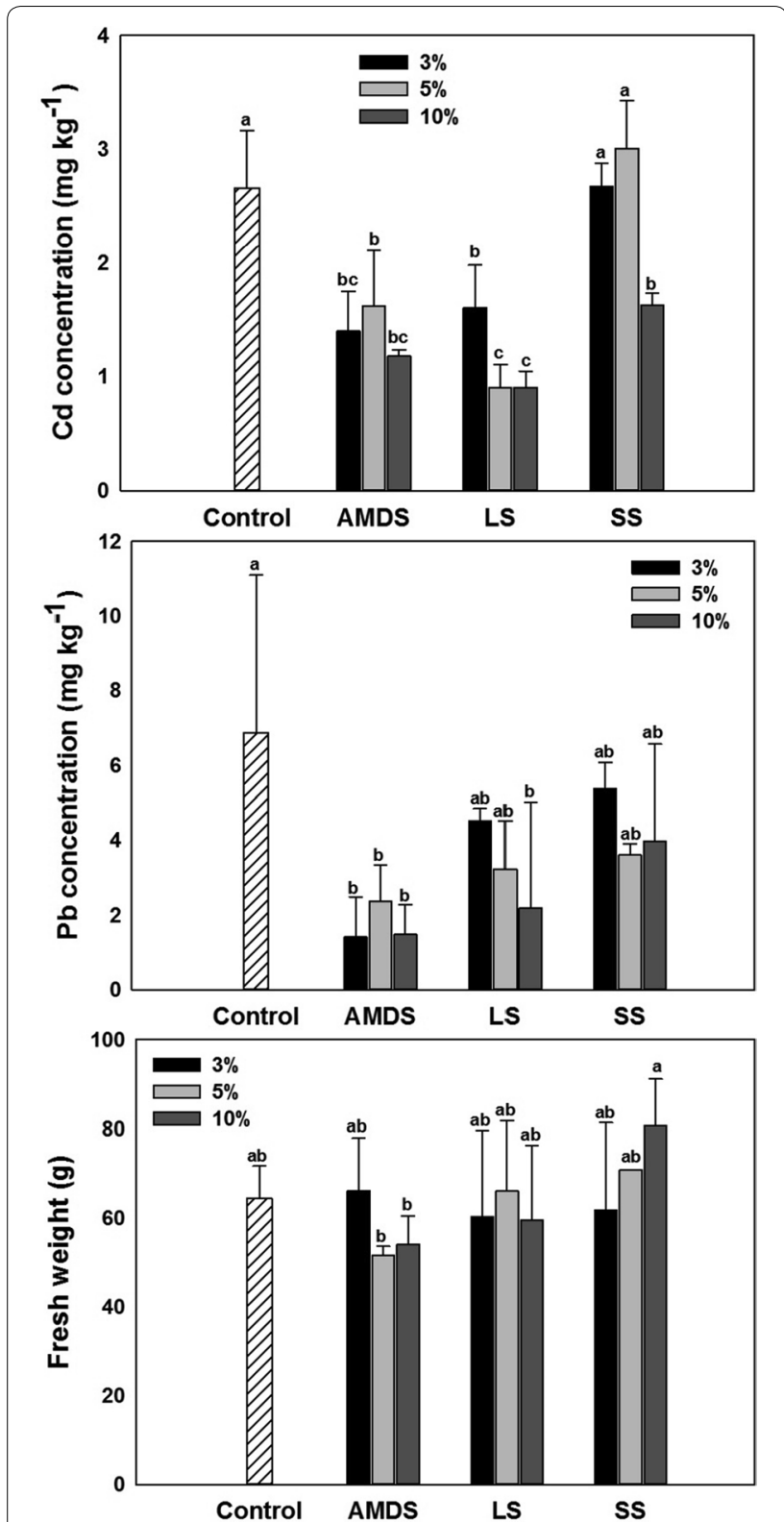

Fig. 2 Heavy metal concentration in the crop and fresh weight of lettuce (Lactuca satva) after 30 days of treatment. All value was an average of triplicate measurement and error bar represent standard deviation. Different letters represent statistical difference at the significance of $p<0.05$

\section{Soil enzyme activities}

The average of triplicate measurements for soil enzyme activity ranged between $0.05-0.15 \mu \mathrm{g}$ soil $^{-1} \mathrm{~h}^{-1}$ for $\beta$-glucosidase and 1.23-4.44 $\mathrm{nmol} \mathrm{g}$ soil ${ }^{-1} \mathrm{~min}^{-1}$ for acid phosphatase (Fig. 4). Compared to the control, no significant difference was observed in the $\beta$-glucosidase treatment, except for the 5\% LS application, which had the highest activity of $\beta$-glucosidase $\left(0.15 \mu \mathrm{g}\right.$ g soil $\left.^{-1} \mathrm{~h}^{-1}\right)$.
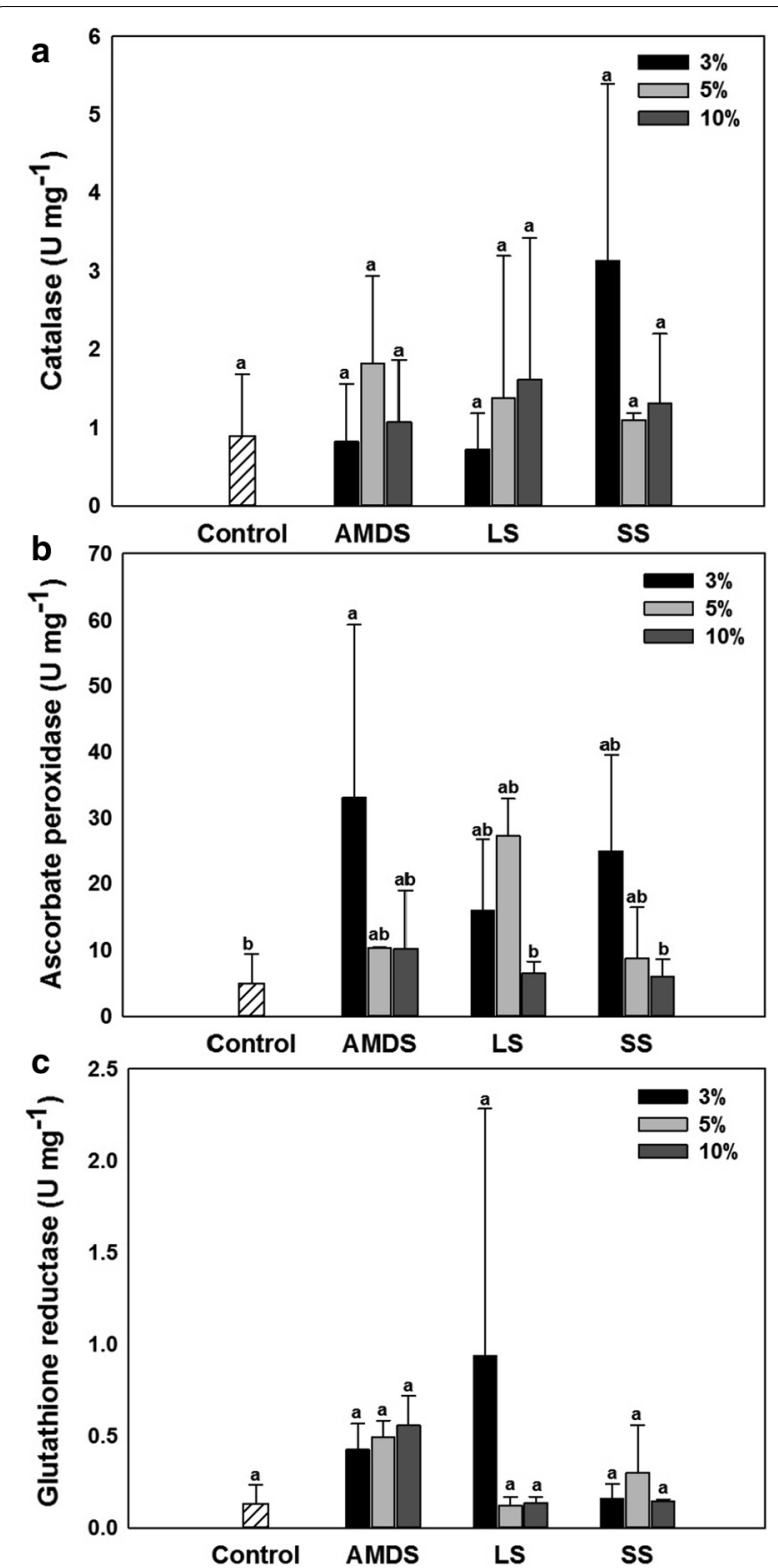

Fig. 3 Antioxidant enzyme activity of each treatments $\mathbf{a}$ CAT, $\mathbf{b}$ APX, c GR. All value was an average of triplicate measurement and error bar represent standard deviation. Different letters represent statistical difference at the significance of $p<0.05$

Although the difference in activity was insignificant, higher activity of $\beta$-glucosidase was observed when AMDS, LS, and SS were applied to the soil compared to the control.

In the case of acid phosphatase, higher activity was observed in AMDS treatment compared to the control, and similar or lower activity was observed in both LS and SS treatments (Fig. 4). The highest acid phosphatase activity was measured in 10\% AMDS (4.44 nmol/g soil/ 

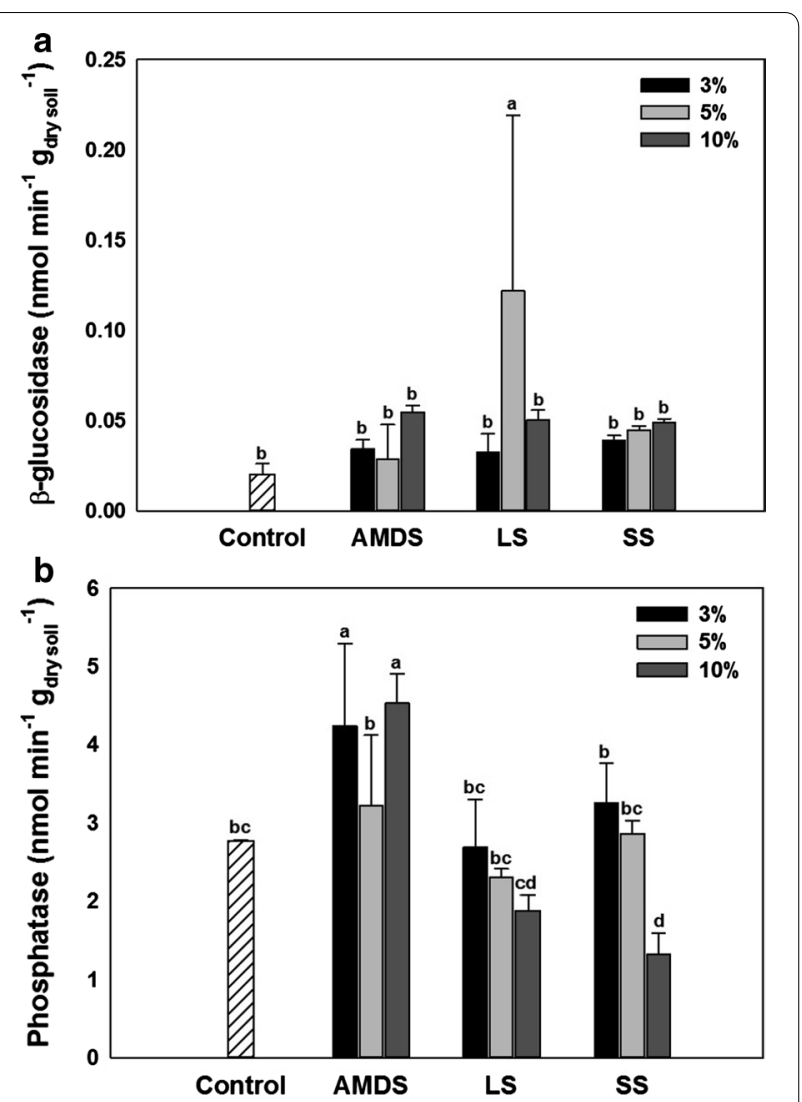

Fig. 4 Soil enzyme activities in each treatments a $\beta$-glucosidase, b Phosphatase. All value was an average of triplicate measurement and error bar represent standard deviation. Different letters represent statistical difference at the significance of $p<0.05$

min) followed by $3 \%$ AMDS (4.14 nmol g soil ${ }^{-1} \mathrm{~min}^{-1}$ ). When LS and SS were applied, the activity of acid phosphatase decreased as the application rate increased.

Soil enzyme activity can be affected by several factors such as soil $\mathrm{pH}, \mathrm{SOM}$, and heavy metal concentration [53]. A previous study showed that the activity of $\beta$-glucosidase decreased when soil $\mathrm{pH}$ increased from 4.3 to 7.4 in paddy soil [54]. Another study, however, identified a positive correlation between soil $\mathrm{pH}$ and $\beta$-glucosidase activity in soil when biochar and compost were applied for heavy metal remediation [55]. These contrast result of correlation between soil $\mathrm{pH}$ and microbial activity explained that microbial activity is highly dependent on surrounding soil environment.

In this study, the correlation analysis in Table 3 showed a significant positive correlation $(\mathrm{p}<0.05)$ between soil $\mathrm{pH}$ and $\beta$-glucosidase activity. This result can be explained by the fact that the addition of amendments improved acidic condition of soil $\mathrm{pH}$ and consequently enhanced soil microbial activity.
Soil pH also impacts activity of phosphatase. Dick et al. [56] reported that soil $\mathrm{pH}$ affects soil enzyme activity in terms of nutrient availability, diversity of microorganism, and effective concentration of substrate in soil solution [56]. As shown in Table 3, strong negative correlation $(\mathrm{p}<0.01)$ was observed between soil $\mathrm{pH}$ and activity of acidic phosphatase indicating that more activity of phosphatase was observed at lower soil pH. Since acid phosphatase was measured in this study, this result agreed with the previous study showing higher activity of acid phosphatase than alkaline phosphatase in acidic condition [56].

Heavy metal concentrations in soil also greatly impact microbial activity. In general, there is a negative correlation between heavy metal concentration and microbial activity. Hu et al. [11] reported that the activity of dehydrogenase, urease, catalase, and acid phosphatase was reduced by $5.3-74.8 \%$ compared to the control because of heavy metal toxicity in soil $[11,31]$. These study concluded that increased bioavailable fractions of heavy metals can inhibit soil enzyme activities by reacting metal ions with the enzyme sulfhydryl group or chelating with enzyme substrate. However, microbial activity can vary when organic or inorganic amendments are applied in soil for heavy metal remediation [55]. Soil microbial activity can be enhanced when heavy metals are used as substrates for microbial activity.

Our study found a positive correlation with $\beta$-glucosidase activity and a negative correlation with phosphatase for both bioavailable $\mathrm{Cd}$ and $\mathrm{Pb}$ concentrations in soil. In particular, a strong negative correlation was observed between bioavailable $\mathrm{Pb}$ concentration and phosphatase activity in soil (Table 3). This result can be interpreted that much higher $\mathrm{Pb}$ concentration compared to $\mathrm{Cd}$ in soil inhibits microbial activity, resulting in reduced phosphatase activity, while impact of soluble $\mathrm{Cd}$ on inhibition of microbial activity was minimal. In addition, phosphatase activity could be more sensitive than $\beta$-glucosidase activity when soil is polluted with heavy metals [29, 57]. Yang et al. [29] tested two different soil enzymes, oxidoreductase and hydrolase, to select the bio-indicator for evaluating heavy metal pollution in soil. This study revealed that amylase (for $\mathrm{C}$ cycling), acid phosphatase (for P cycling), and catalase (for redox reaction) was sensitive to heavy metal pollution showing significantly positive correlation $(\mathrm{p}<0.05)$ with $\mathrm{Pb}, \mathrm{Cd}, \mathrm{Zn}$ concentration.

\section{Conclusion}

The application of three chemical amendments, AMDS, LS, and SS in soil polluted with heavy metals had an effect on soil chemical properties and heavy metal concentrations in soil and plants. The application of LS and 
SS resulted in a significantly higher soil $\mathrm{pH}(\mathrm{p}<0.05)$ than the control and AMDS. However, no significant difference was observed in the reduction of bioavailable $\mathrm{Cd}$ and $\mathrm{Pb}$ in soil. In contrast, significantly lower bioavailable $\mathrm{Pb}$ was observed in the AMDS treatment. This may be attributed to the oxidation of bioavailable heavy metals in soil as the main reduction mechanism in this study.

No significant difference $(\mathrm{p}>0.05)$ was observed for the activity of three antioxidant enzymes, CAT, APX, and GR, compared to the control. However, generally higher antioxidant enzyme activity was measured when chemical amendments were applied. This result could be interpreted that application of amendments had an effect on reducing bioavailable heavy metal concentrations in soil and consequently, decreasing uptake of heavy meals and inhibiting antioxidant activity in plants.

Two soil enzyme activities also increased after chemical amendments were applied to the soil. Reduced bioavailable heavy metals in soil can cause increased microbial activity, resulting in enhanced soil enzyme activity. Comparing sensitivity of two soil enzymes to heavy metal pollution and soil properties, acid phosphatase was more sensitive to soil $\mathrm{pH}$ and heavy metal pollution than $\beta$-glucosidase. Overall, the application of chemical amendments had a positive effect on reducing heavy metals in both soil and plants. It also helped vitalizing plant physiological functions and soil microbial activity in soil.

\section{Acknowledgements}

This study is supported by Korea Ministry of Environment as "Integrated management of surface soil environment with tracking and prediction technology" projects (RE201901260).

\section{Author contributions \\ YK was the first author who mainly write this manuscript. JW and SP organ- ized the experiment, collect a data, and summarize a main finding for the manuscript. JE interpreted a data and gave a comment for improving the manuscript. SC manage and organize a full manuscript as a corresponding author. All authors read and approved the final manuscript.}

\section{Funding}

This study is supported by Korea Ministry of Environment as "Integrated management of surface soil environment with tracking and prediction technology" projects (RE201901260).

\section{Availability of data and materials}

The datasets used and/or analyzed during the current study are available from the corresponding author on reasonable request.

\section{Competing interests}

The authors declare that they have no competing interests.

\section{Author details}

${ }^{1}$ Department of Bio Environmental Chemistry, Chungnam National University, Daejeon 34134, Korea. ${ }^{2}$ Department of Biological Environment, Kangwon National University, Chuncheon 24341, Korea.
Received: 13 May 2020 Accepted: 18 July 2020

Published online: 30 July 2020

\section{References}

1. Zhang Q, Chen H, Xu C, Zhu H, Zhu Q (2019) Heavy metal uptake in rice is regulated by $\mathrm{pH}$-dependent iron plaque formation and the expression of the metal transporter genes. Environ Exp Bot 162:392-398

2. Khan AZ, Khan S, Khan MA, Alam M, AyazT (2020) Biochar reduced the uptake of toxic heavy metals and their associated health risk via rice (Oryza sativa L.) grown in Cr-Mn mine contaminated soils. Environ Technol Innov 17:100590

3. Ahmad M, Usman ARA, Al-Faraj AS, Ahmad M, Sallam A, Al-Wabel Ml (2018) Phosphorus-loaded biochar changes soil heavy metals availability and uptake potential of maize (Zea mays L.) plants. Chemosphere 194:327-339

4. Mao C, Song Y, Chen L, Ji J, Li J, Yuan X, Yang Z, Ayoko GA, Frost RL, Theiss $F(2019)$ Human health risks of heavy metals in paddy rice based on transfer characteristics of heavy metals from soil to rice. CATENA 175:339-348

5. Asgari Lajayer B, Najafi N, Moghiseh E, Mosaferi M, Hadian J (2019) Micronutrient and heavy metal concentrations in basil plant cultivated on irradiated and non-irradiated sewage sludge- treated soil and evaluation of human health risk. Regul Toxicol Pharmacol 104:141-150

6. Liu J, Liu YJ, Liu Y, Liu Z, Zhang AN (2018) Quantitative contributions of the major sources of heavy metals in soils to ecosystem and human health risks: a case study of Yulin, China. Ecotoxicol Environ Saf 164:261-269

7. Gul I, Manzoor M, Hashmi I, Bhatti MF, Kallerhoff J, Arshad M (2019) Plant uptake and leaching potential upon application of amendments in soils spiked with heavy metals (Cd and Pb). J Environ Manzage 249:109408

8. He H, Tam NFY, Yao A, Qiu R, Li WC, Ye Z (2017) Growth and Cd uptake by rice (Oryza sativa) in acidic and Cd-contaminated paddy soils amended with steel slag. Chemosphere 189:247-254

9. Zhai X, Li Z, Huang B, Luo N, Huang M, Zhang Q, Zeng G (2018) Remediation of multiple heavy metal-contaminated soil through the combination of soil washing and in situ immobilization. Sci Total Environ 635:92-99

10. Gong Y, Zhao D, Wang Q (2018) An overview of field-scale studies on remediation of soil contaminated with heavy metals and metalloids: technical progress over the last decade. Water Res 147:440-460

11. Hu P, Yang B, Dong C, Chen L, Cao X, Zhao J, Wu L, Luo Y, Christie P (2014) Assessment of EDTA heap leaching of an agricultural soil highly contaminated with heavy metals. Chemosphere 117:532-537

12. Douay F, Roussel H, Pruvot C, Loriette A, Fourrier H (2008) Assessment of a remediation technique using the replacement of contaminated soils in kitchen gardens nearby a former lead smelter in Northern France. Sci Total Environ 401:29-38

13. Busto Y, Cabrera X, Tack FM, Verloo MG (2011) Potential of thermal treatment for decontamination of mercury containing wastes from chloralkali industry. J Hazard Mater 186:114-118

14. Cui H, Fan Y, Fang G, Zhang H, Su B, Zhou J (2016) Leachability, availability and bioaccessibility of $\mathrm{Cu}$ and $\mathrm{Cd}$ in a contaminated soil treated with apatite, lime and charcoal: a five-year field experiment. Ecotoxicol Environ Saf. 134P1:148-155

15. Bian R, Chen D, Liu X, Cui L, Li L, Pan G, Xie D, Zheng J, Zhang X, Zheng J, Chang A (2013) Biochar soil amendment as a solution to prevent Cdtainted rice from China: results from a cross-site field experiment. Ecol Eng 58:378-383

16. Cui L, Pan G, Li L, Bian R, Liu X, Yan J, Quan G, Ding C, Chen T, Liu Y, Liu Y, Yin C, Wei C, Yang Y, Hussain Q (2016) Continuous immobilization of cadmium and lead in biochar amended contaminated paddy soil: a five-year field experiment. Ecol Eng 93:1-8

17. Abad-Valle P, Álvarez-Ayuso E, Murciego A, Pellitero E (2016) Assessment of the use of sepiolite amendment to restore heavy metal polluted mine soil. Geoderma 280:57-66

18. Liang X, Han J, Xu Y, Sun Y, Wang L, Tan X (2014) In situ field-scale remediation of $\mathrm{Cd}$ polluted paddy soil using sepiolite and palygorskite. Geoderma 235-236:9-18 
19. Choi WS, Hong YK, Min KJ, Kim KJ, Km SC (2017) Evaluating soil respiration as indicator of heavy metal pollution in agricultural field. Kor I Soil Sci Fert 50:472-481

20. Kim HU, Lee MN, Kim HS, Kim KR (2019) Exploration of heavy metal(loid)s immobilizing agents available for agricultural lands and their combination effects. Kor J Soil Sci Fert 52:297-306

21. Nehnevajova E, Lyubenova L, Herzig R, Schröder P, Schwitzguébel J-P, Schmülling T (2012) Metal accumulation and response of antioxidant enzymes in seedlings and adult sunflower mutants with improved metal removal traits on a metal-contaminated soil. Environ Exp Bot 76:39-48

22. Dixit V, Pandey V, Shyam R (2001) Differential antioxidative responses to cadmium in roots and leaves of pea (Pisum sativum L. cv. Azad). J Exp Bot 52:1101-1109

23. Gong H, Zhu X, Chen K, Wang S, Zhang C (2005) Silicon alleviates oxidative damage of wheat plants in pots under drought. Plant Sci 169:313-321

24. Garcia JS, Gratao PL, Azevedo RA, Rarruda MAZ (2006) Metal contamination effects on sunflower (Helianthus annuus L.) growth and protein expression in leaves during development. J Agric Food Chem 54:8623-8630

25. Laspina NV, Groppa MD, Tomaro ML, Benavides MP (2005) Nitric oxide protects sunflower leaves against $\mathrm{Cd}$-induced oxidative stress. Plant Sci 169:323-330

26. Shahkolaie SS, Baranimotlagh M, Dordipour E, Khormali F (2020) Effects of inorganic and organic amendments on physiological parameters and antioxidant enzymes activities in Zea mays L. from a cadmium-contaminated calcareous soil. S Afr J Bot 128:132-140

27. Han Y, Wu X, Gu J, Zhao J, Huang S, Yuan H, Fu J (2016) Effects of organic acids on the photosynthetic and antioxidant properties and accumulations of heavy metals of Melilotus officinalis grown in Cu tailing. Environ Sci Pollut Res Int 23:17901-17909

28. Meers E, Ruttens A, Geebelen W, Vangronsveld J, Samson R, Vanbroekhoven K, Vandegehuchte M, Diels L, Tack FM (2006) Potential use of the plant antioxidant network for environmental exposure assessment of heavy metals in soils. Environ Monit Assess 120:243-267

29. Yang J, Yang F, Yang Y, Xing G, Deng C, Shen Y, Luo L, Li B, Yuan H (2016) A proposal of "core enzyme" bioindicator in long-term $\mathrm{Pb}$-Zn ore pollution areas based on topsoil property analysis. Environ Pollut 213:760-769

30. Liao M, Xie XM (2007) Effect of heavy metals on substrate utilization pattern, biomass, and activity of microbial communities in a reclaimed mining wasteland of red soil area. Ecotoxicol Environ Saf 66:217-223

31. Hu X-F, Jiang Y, Shu Y, Hu X, Liu L, Luo F (2014) Effects of mining wastewater discharges on heavy metal pollution and soil enzyme activity of the paddy fields. J Geochem Explor 147:139-150

32. Liang $Q$, Gao R, Xi B, Zhang Y, Zhang H (2014) Long-term effects of irrigation using water from the river receiving treated industrial wastewater on soil organic carbon fractions and enzyme activities. Agric Water Manag 135:100-108

33. Song J, Shen Q, Wang L, Qiu G, Shi J, Xu J, Brookes PC, Liu X (2018) Effects of $\mathrm{Cd}, \mathrm{Cu}, \mathrm{Zn}$ and their combined action on microbial biomass and bacterial community structure. Environ Pollut 243:510-518

34. Francisca FM, Glatstein DA (2020) Environmental application of basic oxygen furnace slag for the removal of heavy metals from leachates. $J$ Hazard Mater 384:121294

35. Garau G, Castaldi P, Santona L, Deiana P, Melis P (2007) Influence of red mud, zeolite and lime on heavy metal immobilization, culturable heterotrophic microbial populations and enzyme activities in a contaminated soil. Geoderma 142:47-57

36. Yoon D-H, Choi WS, Hong YK, Lee YB, Kim SC (2019) Effect of chemical amendments on reduction of bioavailable heavy metals and ecotoxicity in soil. Appl Biol Chem 62:53

37. Mehmood S, Saeed DA, Rizwan M, Khan MN, Aziz O, Bashir S, Ibrahim M, Ditta A, Akmal M, Mumtaz MA, Ahmed W, Irshad S, Imtiaz M, Tu S, Shaheen A (2018) Impact of different amendments on biochemical responses of sesame (Sesamum indicum L.) plants grown in lead-cadmium contaminated soil. Plant Physiol Biochem 132:345-355

38. Dai H, Wei S, Skuza L, Jia G (2019) Selenium spiked in soil promoted zinc accumulation of Chinese cabbage and improved its antioxidant system and lipid peroxidation. Ecotoxicol Environ Saf 180:179-184
39. Turan V (2019) Confident performance of chitosan and pistachio shell biochar on reducing Ni bioavailability in soil and plant plus improved the soil enzymatic activities, antioxidant defense system and nutritional quality of lettuce. Ecotoxicol Environ Saf 183:109594

40. Hussain Lahori A, Zhang Z, Guo Z, Mahar A, Li R, Kumar Awasthi M, Ali Sial T, Kumbhar F, Wang P, Shen F, Zhao J, Huang H (2017) Potential use of lime combined with additives on (im)mobilization and phytoavailability of heavy metals from $\mathrm{Pb} / \mathrm{Zn}$ smelter contaminated soils. Ecotoxicol Environ Saf 145:313-323

41. Rakotonimaro TV, Neculita CM, Bussière B, Benzaazoua M, Zagury GJ (2017) Recovery and reuse of sludge from active and passive treatment of mine drainage-impacted waters: a review. Environ Sci Pollut Res 24:73-91

42. Ko M-S, Kim J-Y, Park H-S, Kim K-W (2015) Field assessment of arsenic immobilization in soil amended with iron rich acid mine drainage sludge. J Clean Product 108:1073-1080

43. Gray CW, Dunham SJ, Dennis PG, Zhao FJ, McGrath SP (2006) Field evaluation of in situ remediation of a heavy metal contaminated soil using lime and red-mud. Environ Pollut 142:530-539

44. Novak JM, Ippolito JA, Ducey TF, Watts DW, Spokas KA, Trippe KM, Sigua GC, Johnson MG (2018) Remediation of an acidic mine spoil: miscanthus biochar and lime amendment affects metal availability, plant growth, and soil enzyme activity. Chemosphere 205:709-718

45. Cui H, Shi Y, Zhou J, Chu H, Cang L, Zhou D (2018) Effect of different grain sizes of hydroxyapatite on soil heavy metal bioavailability and microbial community composition. Agric Ecosyst Environ 267:165-173

46. Yun JJ, Kang BH, Kang SW, Kim SY, Seo DC, Cho JS (2018) Effect of fertilizers using Ferro-nickel slag on Chinese cabbage growth and soil chemical properties. Kor J Soil Sci Fert 51:204-210

47. Ownby DR, Galvan KA, Lydy MJ (2005) Lead and zinc bioavailability to Eisenia fetida after phosphorus amendment to repository soils. Environ Pollut 136:315-321

48. Yan Y, Qi F, Seshadri B, Xu Y, Hou J, Ok YS, Dong X, Li Q, Sun X, Wang L, Bolan N (2016) Utilization of phosphorus loaded alkaline residue to immobilize lead in a shooting range soil. Chemosphere 162:315-323

49. Zulfiqar U, Farooq M, Hussain S, Maqsood M, Hussain M, Ishfaq M, Ahmad M, Anjum MZ (2019) Lead toxicity in plants: impacts and remediation. J Environ Manage 250:109557

50. Edelstein M, Ben-Hur M (2018) Heavy metals and metalloids: sources, risks and strategies to reduce their accumulation in horticultural crops. Sci Hortic 234:431-444

51. Qin S, Liu H, Nie Z, Rengel Z, Gao W, Li C, Zhao P (2020) Toxicity of cadmium and its competition with mineral nutrients for uptake by plants: a review. Pedosphere 30:168-180

52. Saavedra-Mella F, Liu Y, Southam G, Huang L (2019) Phosphate treatment alleviated acute phytotoxicity of heavy metals in sulfidic $\mathrm{Pb}-\mathrm{Zn}$ mine tailings. Environ Pollut 250:676-685

53. Adetunji AT, Lewu FB, Mulidzi R, Ncube B (2017) The biological activities of $\beta$-glucosidase, phosphatase and urease as soil quality indicators: a review. J Soil Sci Plant Nutr 17:794-807

54. Wang X-C, Lu Q (2006) Beta-glucosidase activity in paddy soils of the Taihu Lake Region China. Pedosphere 16:118-124

55. Tang J, Zhang L, Zhang J, Ren L, Zhou Y, Zheng Y, Luo L, Yang Y, Huang H, Chen A (2020) Physicochemical features, metal availability and enzyme activity in heavy metal-polluted soil remediated by biochar and compost. Sci Total Environ 701:134751

56. Dick WA, Cheng L, Wang P (2000) Soil acid and alkaline phosphatase activity as pH adjustment indicators. Soil Biol Biochem 32:1915-1919

57. Tang J, Zhang J, Ren L, Zhou Y, Gao J, Luo L, Yang Y, Peng Q, Huang H, Chen A (2019) Diagnosis of soil contamination using microbiological indices: a review on heavy metal pollution. J Environ Manage 242:121-130

\section{Publisher's Note}

Springer Nature remains neutral with regard to jurisdictional claims in published maps and institutional affiliations. 